\title{
Analysis and Design of Continuous Water Distribution System against Existing Intermittent Distribution System for Selected Area in Pandharpur, M.S., INDIA
}

\author{
Laxman Netaji Kawathe ${ }^{1 *}$, Akshay Rajan Thorvat ${ }^{2}$
}

${ }^{1}$ Department of Environmental Engineering, Kolhapur Institute of Technology’s College of Engineering (Autonomous), Kolhapur, Maharashtra, INDIA

*Corresponding Author: l.kawathe17@gmail.com

Citation: Kawathe, L. N., \& Thorvat, A. R. (2020). Analysis and Design of Continuous Water Distribution System against Existing Intermittent Distribution System for Selected Area in Pandharpur, M.S., INDIA. Aquademia, 4(2), ep20028. https://doi.org/10.29333/aquademia/9136

\begin{abstract}
ARTICLE INFO
Received: 9 Jul. 2020

Accepted: 11 Aug. 2020

ABSTRACT

In infrastructural development the public drinking water distribution network which includes pipes, bents, valves, pumps, tanks etc. is one of the major investments. The design, modeling of distribution network with efficient outcome is an important task. Therefore, the present study is aimed at design of continuous as well as intermittent water distribution systems with adequate water pressure with the use of WaterGEMS Vi8 software. The study is carried out for Manisha Nagar and Padmavati in Pandharpur, Maharashtra. The system comprised of a pipeline network consisting of one source node and several demand nodes is considered to find its optimal geometrical layout which delivers known demands from source to consumers over a long period of time. The effect of forecasted resident population and floating population on demand, head loss gradient, pressure gradient is analyzed. This study is carried out for immediate stage - Year 2021, intermediate stage - Year 2036 and final stage - Year 2051. From the analysis it is observed that, as population increases from year 2021 to 2051, the demand, head loss gradient and pressure development increases.
\end{abstract}

Keywords: floating population, gross demand, hydraulic model, optimal geometrical layout, population forecasting, water distribution network

\section{INTRODUCTION}

No rule or equation may represent the value of water to survive in human, plant and animal forms. Without water a lifecycle on this earth cannot proceed. In ancient times, human beings tend to live in communities close to natural water sources the river or small water channel to satisfy the need for survival water. Water is a major factor that can be socially politically, etc., highly impacting human life (Urban Water II, 2014).

Water is one of the most basic amenities that every living creature needs. Apart from using the water for domestic needs, since man occupied this earth, water resources were the most widely exploited natural system. Other beneficial uses of water include electric power generation, transport, recreation and many other uses for industries. Not only does the use of water escalate exponentially with population growth, but there is also an acute shortage of surface and deep water due to many manmade practices, and man himself has been the root cause of many issues and proper management water use, which having vital importance in this era (Punmia et al., 1995).
Intermittent water supply systems do not operate as designed. Therefore, reservoir capacities are often underutilized. The valves suffer wear and tear. Since, water is supplied by zoning the distribution system, more man power is required. Pipes are empty during non-supply hours and dirt water enters pipes at vulnerable spots and contaminates. In order to make water safe from microbial contamination, large doses of chlorine or other disinfectants are needed Due to the limited hours, in most networks; the peak factor is often within the range of 4 to 6 . Inconvenient supply hours affect poor people. Tanks with large storage capacity are required and consumers have to pay for pumping. It also leads to poor sanitation practices which lead to increased health risks and mortality. Many meters go out of control due to intermittent water supply contributing to loss of revenue. In fact, customers store a significant volume of water and waste it before harvesting fresh water again due to Uncertainty. This leads to an immense unnecessary wastage of treated precious water (Dahasahasra, 2007).

24 X 7 continuous, pressurized water supply overcomes shortfalls in intermittent supply and ensures comfort for the user and helps the vulnerable. Continuous high-quality water supply system decreases the risk of contamination as the pipes 

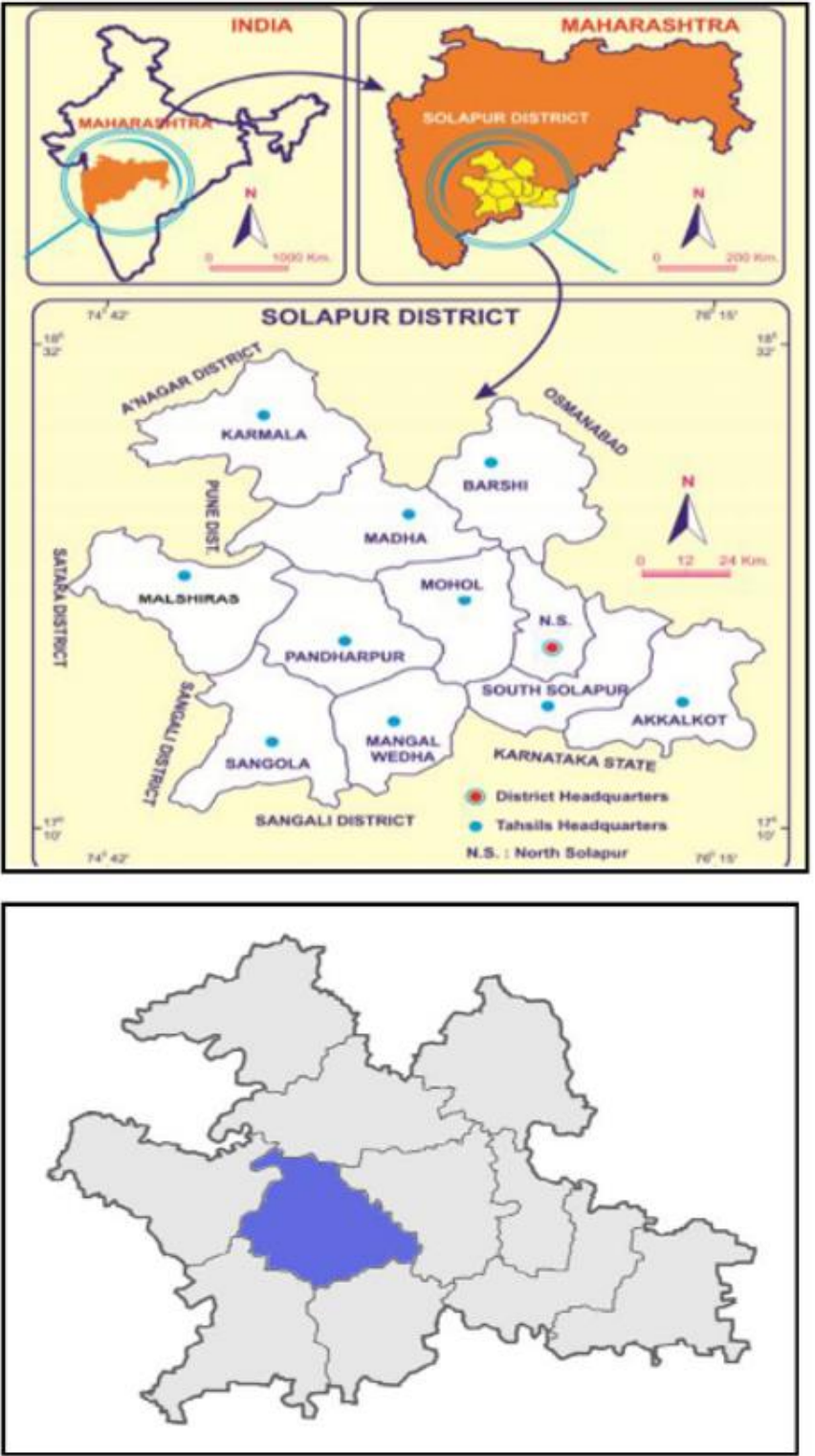

Figure 1. Location Map of Study Area ( Laxman, 2016)

are under positive pressure and contaminants reaching the pipes are limited. Life of distribution networks increases as less variation in pressure in the pipes causes less physical damage to the pipes. Effective demand monitoring is possible due to extensive metering and efficient regulation of leakage. It also results in less storage of water or none at all, which in reduces wastage of water. Continuous supply of pure water boosts the economy and attracts more industries and businesses (Dahasahasra, 2007).

The consideration of this risk and its different components and assessments are the key criteria under which the system can be defined. Its operation, thus, it is a key factor in supply and distribution system operation and planning decision making. At present, distribution system risk assessment is not a general practice. There are several reasons for this, the main one is probably the lack of a generally accepted method for its calculation, which is due to the particular problems involved in distribution networks in terms of the difficulty of being able to rely on reliable information on its actual operating system and to have a sound knowledge base on which to determine the likelihood of incidents occurring (Cubillo \& Pérez, 2014).
The software provide required standard and economical environment for design, analysis and trouble shooting of new and existing supply network with minimum time duration. With software we can identify and solve all types of problems in new as well as existing network. The software is also used for expansion of existing water distribution network (Rajeshwari \& Kumar, 2014).

By using WaterGEMS the operation of the system will be so easy and if some problem is noted than it can be tracked easily by the software. There are so many different type of tools used for the water distribution system that included is different literature, but as compared to others, WaterGEMS is more accurate (Pathan \& Kahalekar, 2015).

The present study aims to design continuous water supply, modeling of network system by using WaterGEMS software for Elevated Storage Reservoirs (ESRs) located at Manisha Nagar and Padmavati in Pandharpur, Maharashtra, India. Study also includes the detailed cost analysis for the project.

\section{SITE LOCATION}

Pandharpur is a pilgrimage town on the bank of Bhima River in Solapur district, Maharashtra, India. It is connected by asphalt road to all district places in Maharashtra. This town is located at Latitude $17^{\circ} 40^{\prime} 24.84^{\prime \prime} \mathrm{N}$ and Longitude $75^{\circ} 19^{\prime} 31.38^{\prime \prime}$ E. Figure 1 shows location map of the study area. Bhima River flowing along the northern boundary of the town takes sharps turn of $90^{\circ}$ and flows along Eastern boundary of the town. The ground is sloping towards north and east. As per 2011 census the Pandharpur Municipal Council has population of 98,923. Pandharpur lies in the area of comparatively dry regions in the state. The temperature ranges from $42^{\circ} \mathrm{C}$ to $8^{\circ} \mathrm{C}$ during summer and the winter months respectively. In general rainfall in the region is scanty with average rainfall of 497.18 $\mathrm{mm}$. The present study is carried out for Manisha Nagar and Padmavati in Pandharpur. Manisha Nagar has largest ESR and Padmavati has large population density. These areas cover almost $2 / 3^{\text {rd }}$ area of Pandharpur.

\section{METHODOLOGY}

\section{General}

The methodology followed in the designing of water distribution network is shown in Figure 2. There are various supporting analyses required to be carries out in various software and tools such as MS Excel, QGIS and WaterGEMS. Figure 2 shows the procedure data collection and analysis in WaterGEMS.

\section{System layout}

The field survey is carried out to track the entire water supply network starting from the source to the consumer end with the help of My Elevation Android Application. The field data is collected and recorded for further analysis.

\section{Data entry}

With the help of collected data and ArcGIS software, maps are prepared for various elements of water supply system. The 


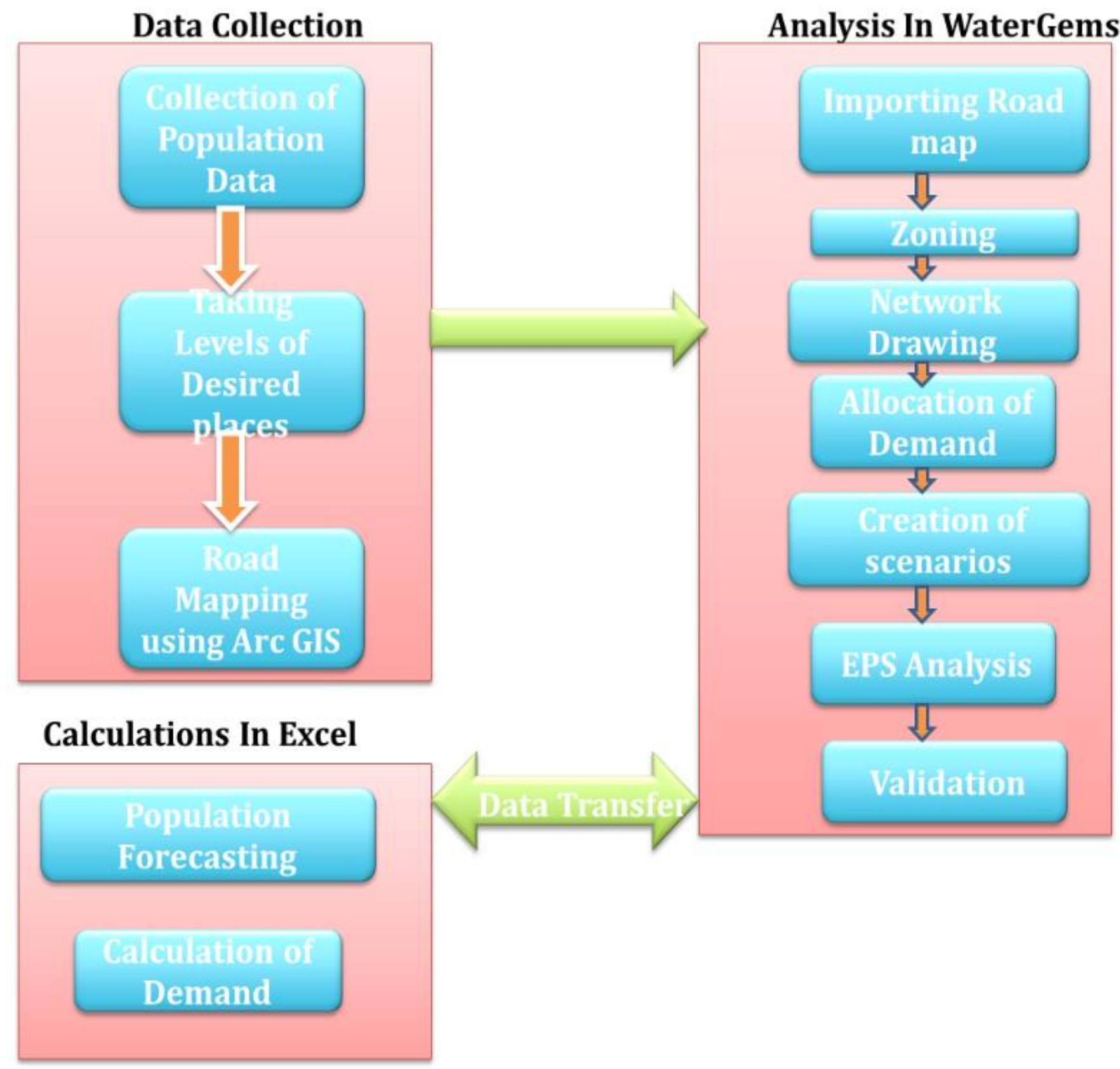

Figure 2. Procedure for Data Collection and Analysis in WaterGEMS

data stored in the attribute table is in form of diameter, material, head, flow, power, Ground Level (GL), Low Supply Level (LSL) and Full Supply Level (FSL) etc. After authenticating the maps with the Municipal Council, hydraulic modeling is done. The data is checked and verified for the details such as, pumping details, diameter of tank, outlet flow in Million Litres per Day (MLD), hydraulic grade in m, demand of each junction in MLD, water pressure in $\mathrm{m}$, hydraulic grade in $\mathrm{m}$, Head loss gradient in $\mathrm{m} / \mathrm{km}$ and velocity in $\mathrm{m} / \mathrm{s}$ through each pipe. Then with the help of Model Builder, the shape files are added to WaterGEMS v8i software.

\section{Population forecasting and demand calculation}

As per guidelines specified in Central Public Health and Environmental Engineering Organization (CPHEEO) Manual on Water Supply and Treatment, Government of India guidelines, the population is forecasted for the next 30 years from the base design period. The losses are considered as $10 \%$ of gross water demand supplied through distribution system (CPHEEO, 1999). This study is carried out for immediate stage - Year 2021, intermediate stage - Year 2036 and final stage Year 2051. The demand calculations are carried out. Thiessen Polygon for all the nodes of the distribution is created and with the help of Load Builder, the demand to the respective junction/node is assigned.

\section{Validation}

See Figures 3-5. 


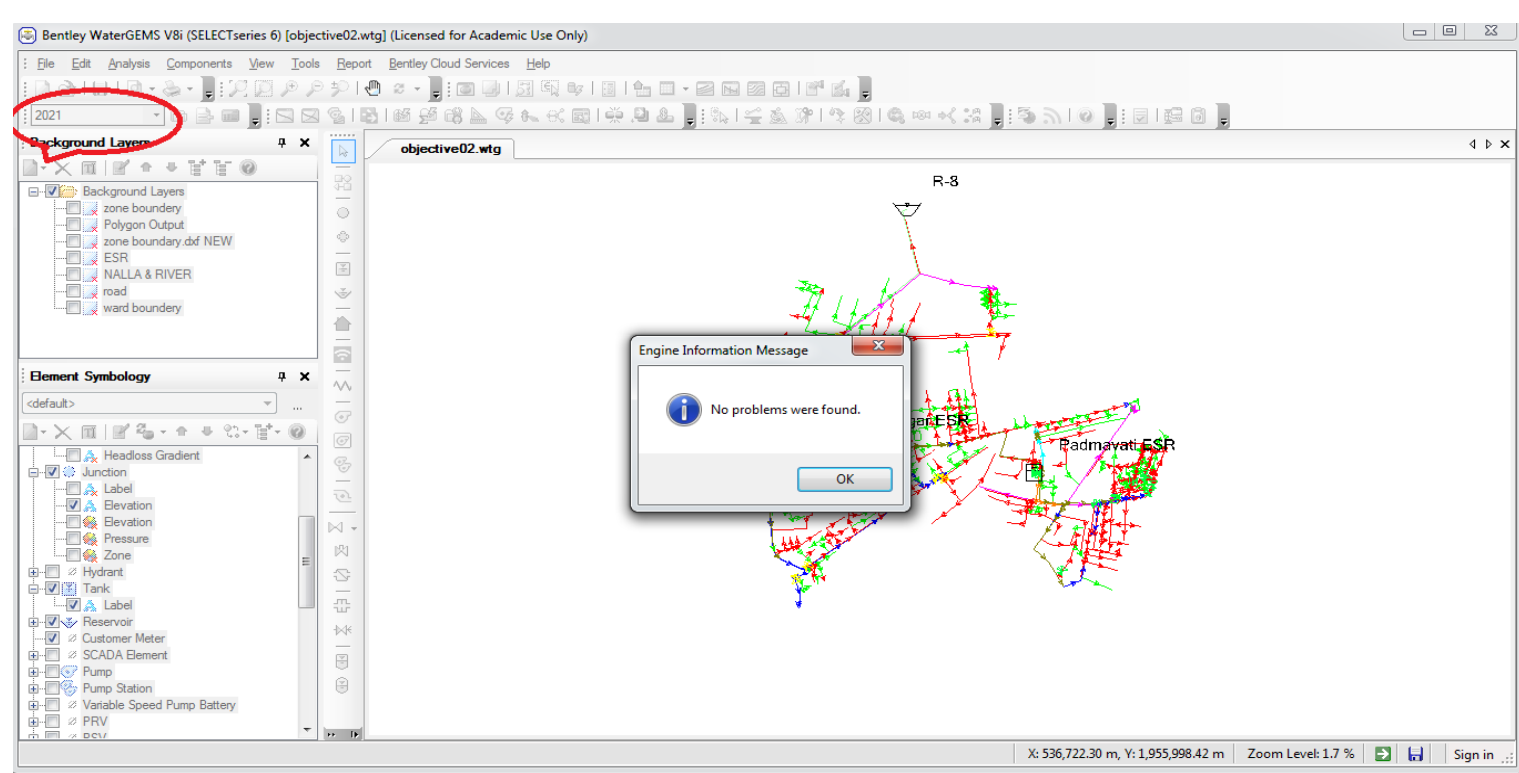

Figure 3. Validation of Immediate Stage

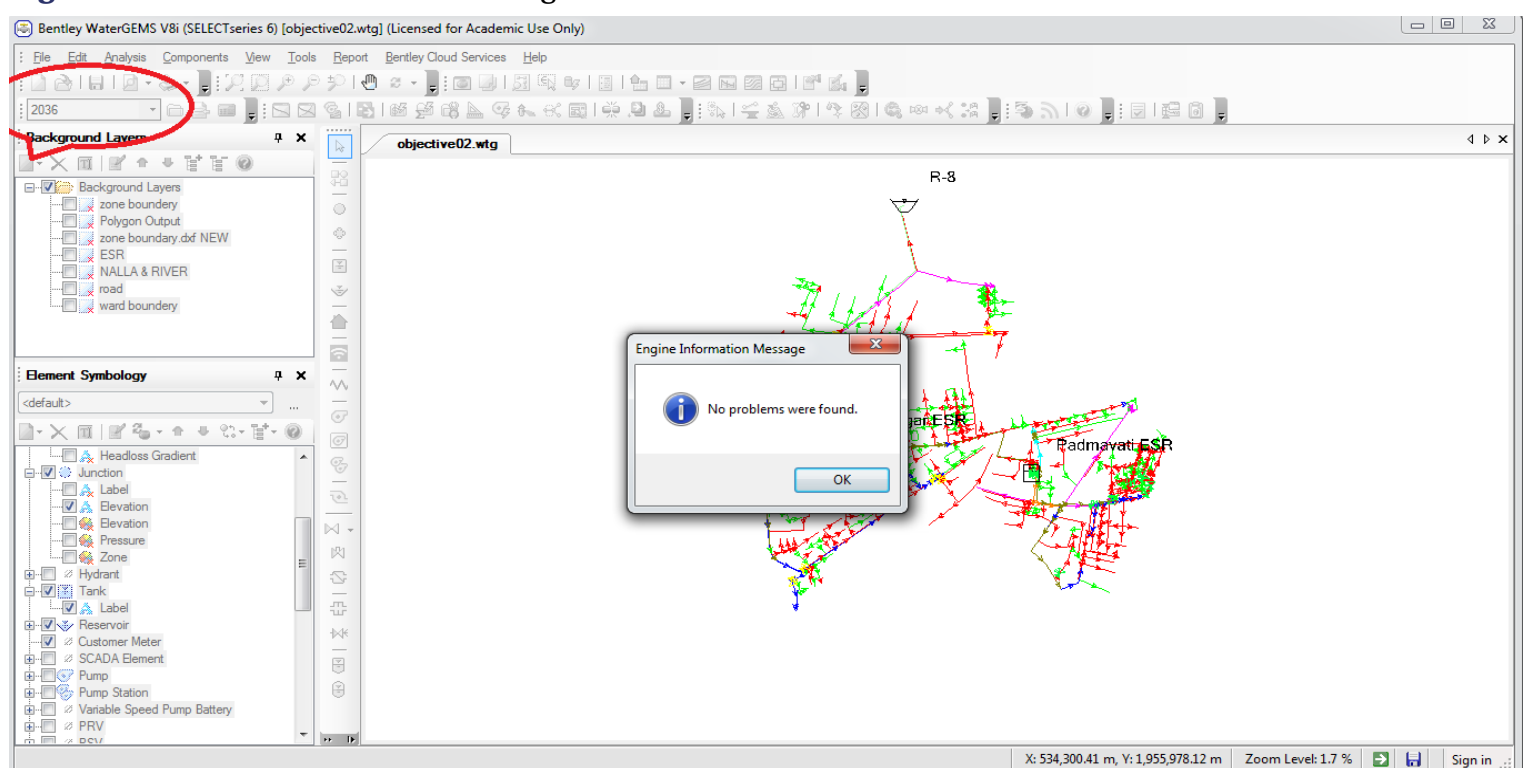

Figure 4. Validation of Intermediate Stage

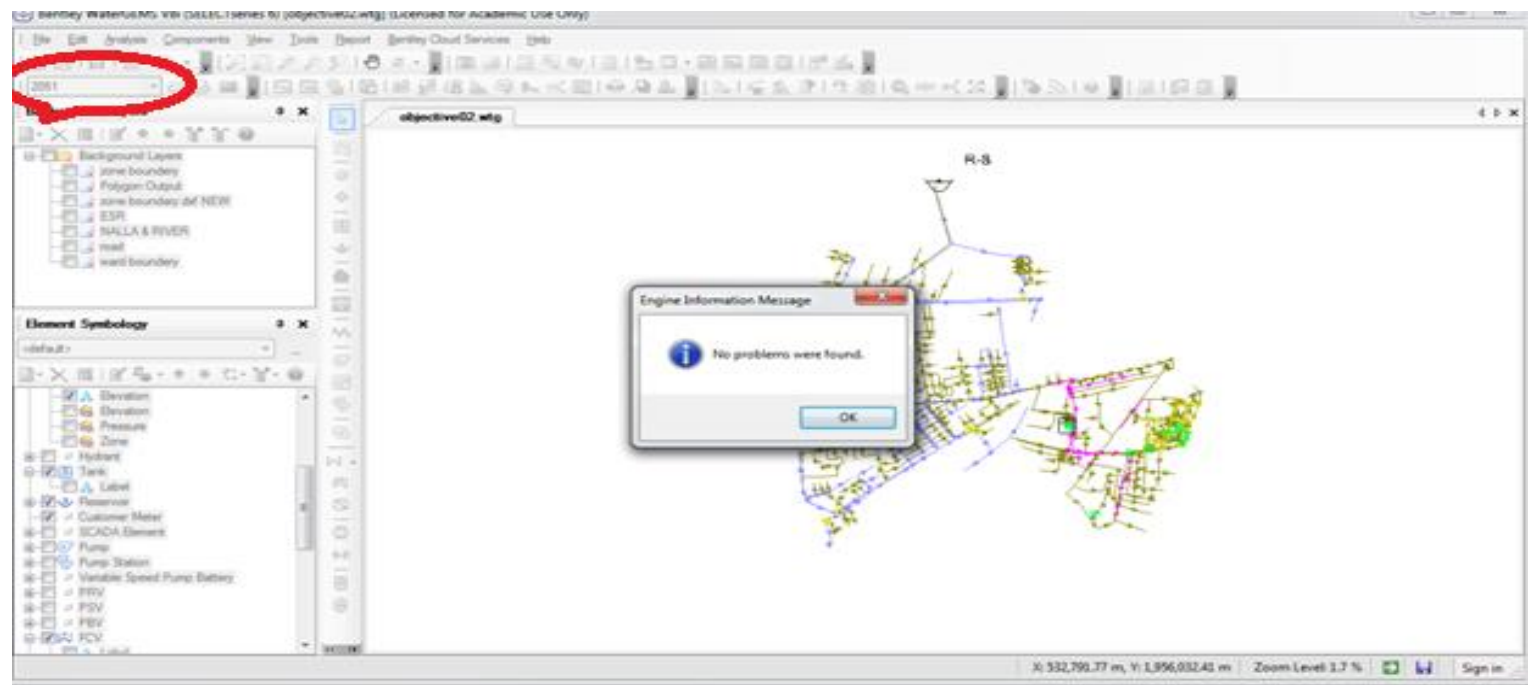

Figure 5. Validation of Final Stage 
Table 1. Details of Gross Demand for Manisha Nagar and Padmavati

\begin{tabular}{|c|c|c|c|c|c|c|c|}
\hline Location & Year & Population & $\begin{array}{l}\text { Rate of Water } \\
\text { Supply (LPCD)* }\end{array}$ & $\begin{array}{l}\text { Net Residential } \\
\text { Water Demand }\end{array}$ & $\begin{array}{l}\text { Institutional / } \\
\text { Commercial } \\
\text { Demand }\end{array}$ & Net Demand & $\begin{array}{l}\text { Gross Demand } \\
\text { in MLD with } \\
10 \% \text { losses }\end{array}$ \\
\hline \multirow{3}{*}{$\begin{array}{c}\text { Manisha Nagar } \\
\text { ESR }\end{array}$} & 2021 & 15891 & 135 & 2.15 & 0.4 & 2.55 & 2.83 \\
\hline & 2036 & 19910 & 135 & 2.69 & 0.58 & 3.27 & 3.63 \\
\hline & 2051 & 24522 & 135 & 3.31 & 0.85 & 4.16 & 4.62 \\
\hline \multirow{3}{*}{ Padmavati ESR } & 2021 & 10871 & 135 & 1.47 & 0.3 & 1.77 & 1.97 \\
\hline & 2036 & 12292 & 135 & 1.66 & 0.36 & 2.02 & 2.24 \\
\hline & 2051 & 13885 & 135 & 1.87 & 0.48 & 2.35 & 2.61 \\
\hline
\end{tabular}

* $L P C D=$ Litres per Capita per Day

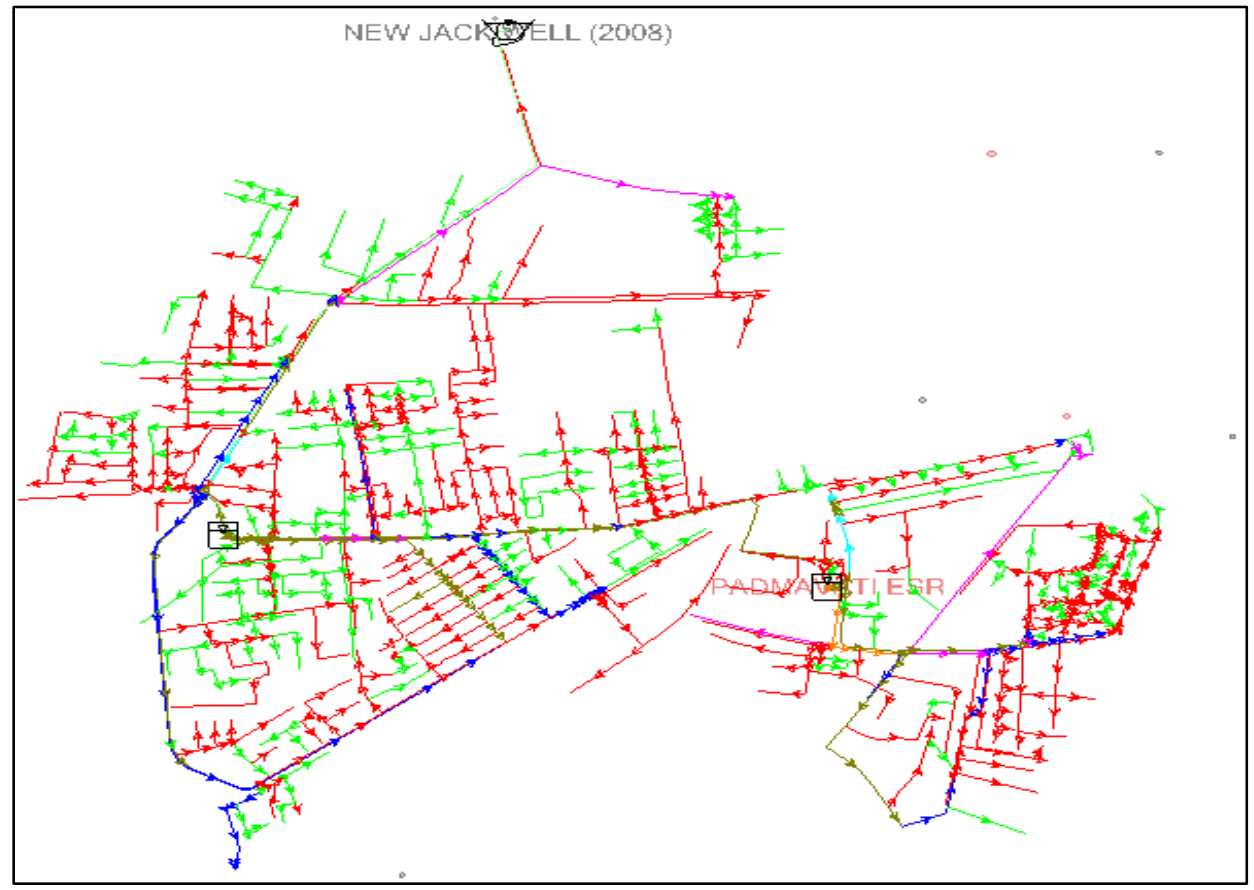

Figure 6. Hydraulic Model of Water Distribution Network

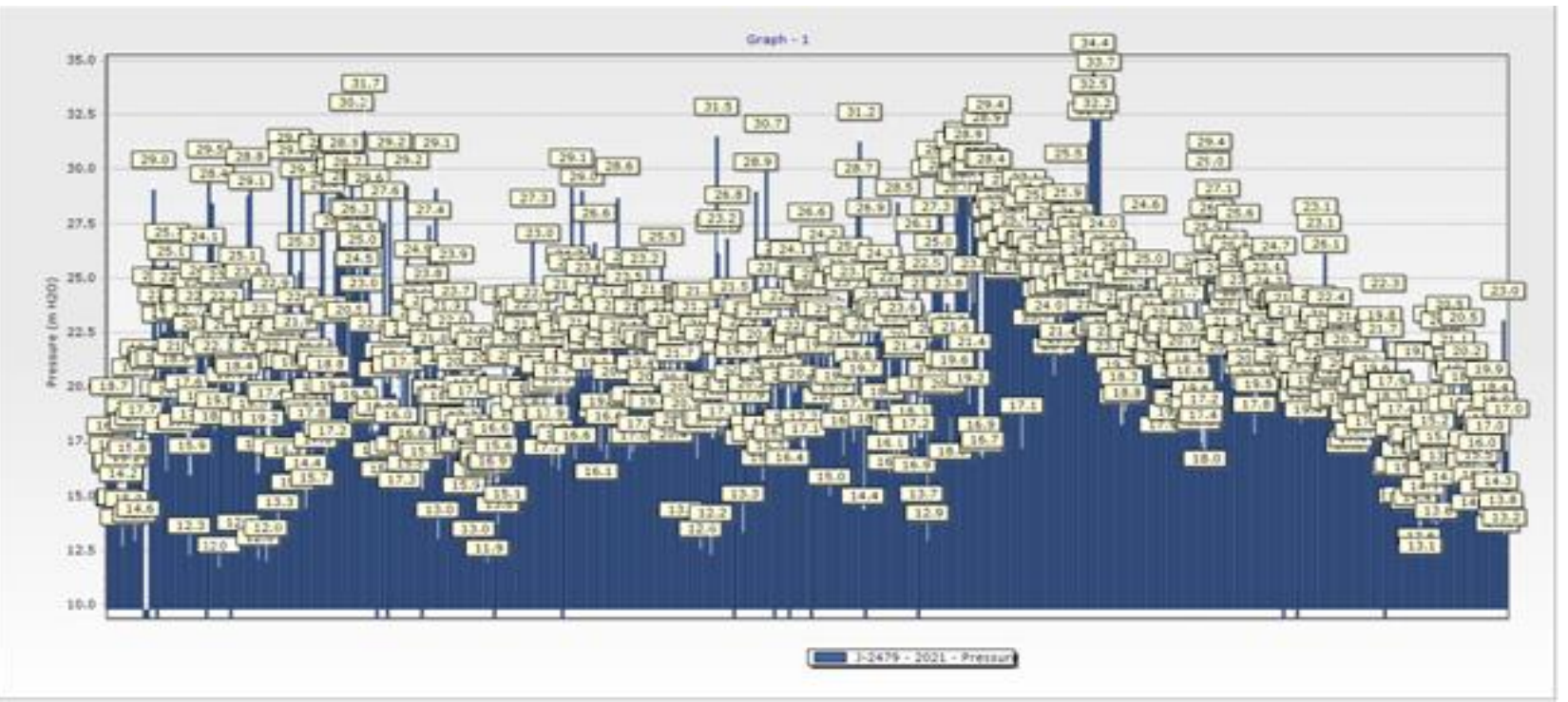

Figure 7. Pressure at Different Junctions for Immediate Stage-2021

\section{RESULTS AND DISCUSSION}

\section{Demand Calculations}

Gross Demand which include net residential water demand, Institutional/ commercial demand, losses for ESRs located at Manisha Nagar and Padmavati is represented in Table 1. 


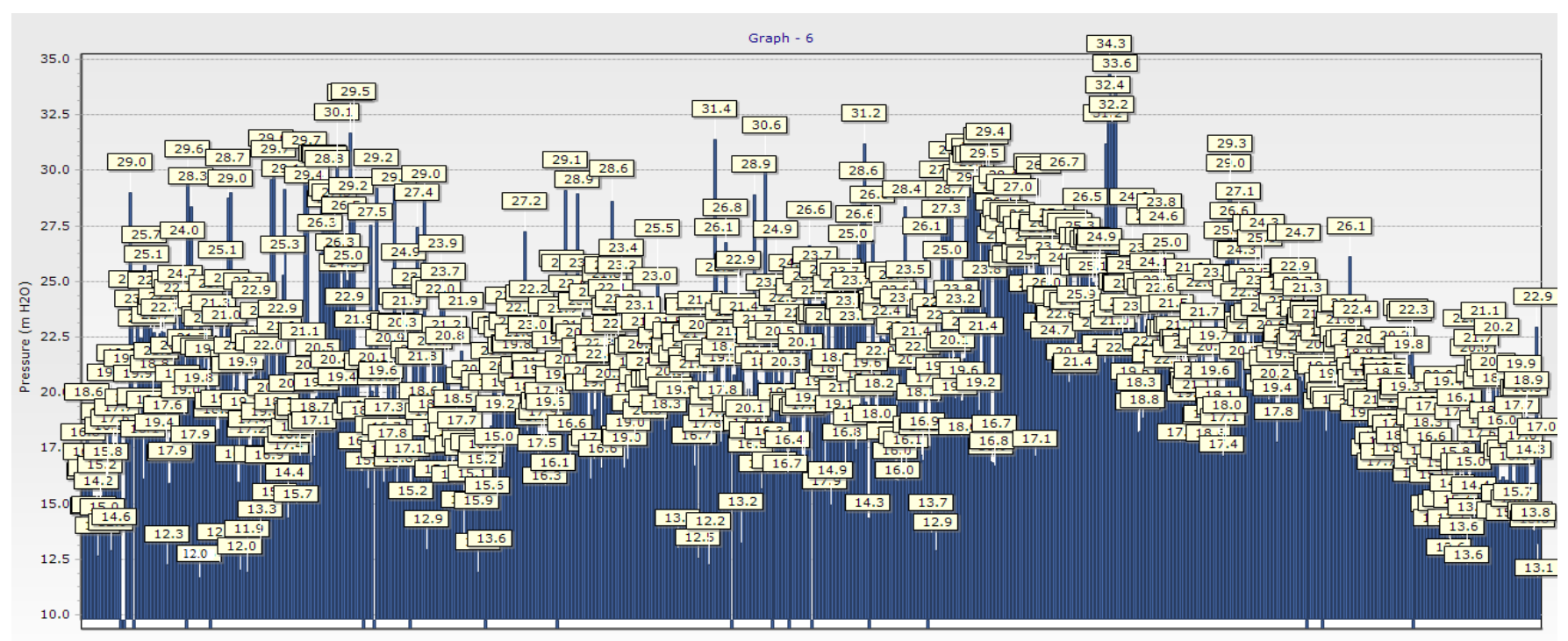

J-2479-2036-Pressur

Figure 8. Pressure at Different Junctions for Intermediate Stage-2036

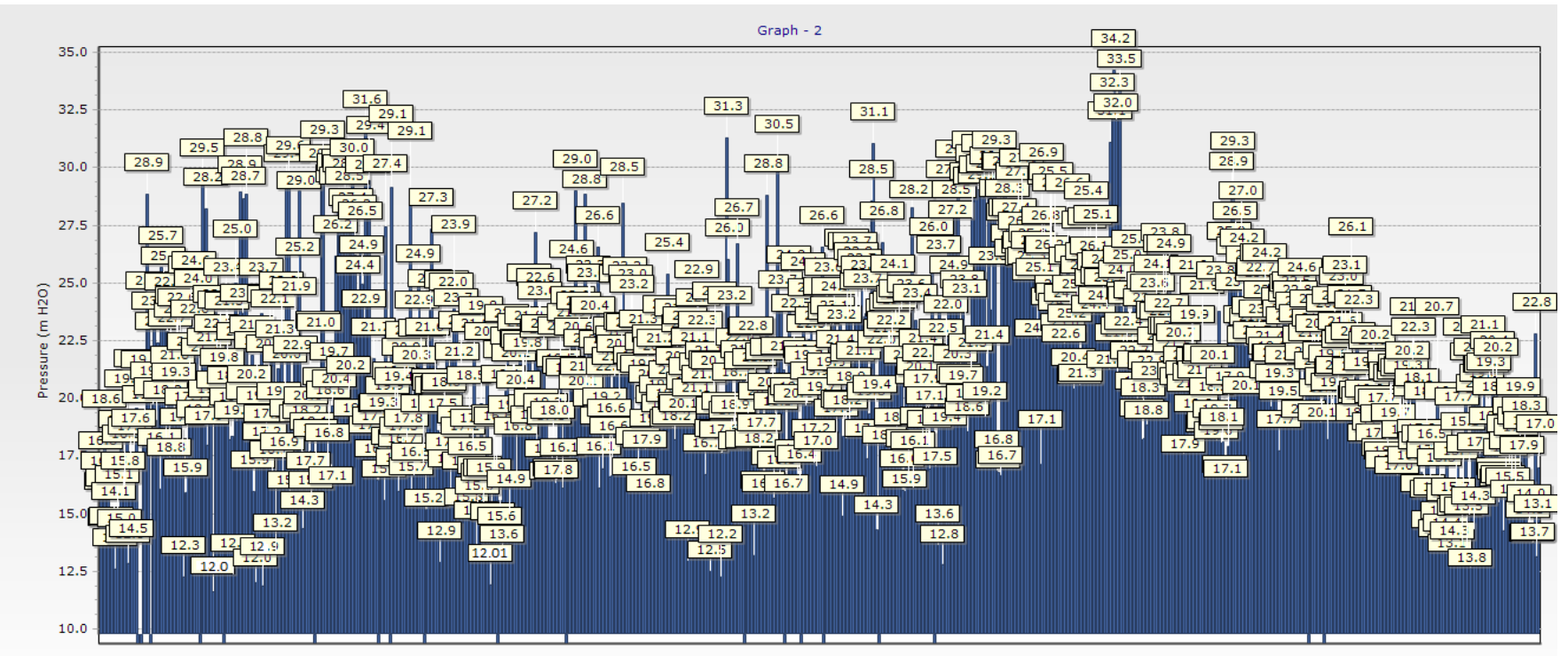

J-2479-2051 - Pressur

Figure 9. Pressure at Different Junctions for Final Stage-2051

\section{Immediate Stage}

It is observed that, for immediate stage (Year - 2021), the minimum pressure is $12.0 \mathrm{~m}$ of water column at junction (J2126) and maximum pressure is $34.4 \mathrm{~m}$ of water column at junction (J-2314).

\section{Intermediate Stage}

It is observed that, for Intermediate Stage (Year - 2036), the minimum pressure is $12.0 \mathrm{~m}$ of water column at junction (J-2126) and maximum pressure is $34.3 \mathrm{~m}$ of water column at junction (J-2314).

\section{Final Stage}

It is observed that, for Final Stage (Year - 2051), the minimum pressure for this stage is $12.0 \mathrm{~m}$ of water column at junction (J-2128) and maximum pressure is $34.2 \mathrm{~m}$ of water column at junction (J-2314).

\section{Estimation and Costing}

HDPE pipe of working pressure $16 \mathrm{~kg} / \mathrm{m}^{2}$ and $\mathrm{K}-7$ ductile iron pipes are used. Table 2 shows the length of pipes and their respective cost in rupees. Table 3 shows estimation and costing for excavation and filling work and Table 4 shows miscellaneous expenses.

The total cost of project includes cost of pipes, cost of excavation and filling work and miscellaneous expenses. Table 5 shows the summary of total cost of project. 
Table 2. Estimation and Costing of Pipes

\begin{tabular}{|c|c|c|c|c|c|}
\hline Diameter (mm) & $\begin{array}{c}\text { Length of HDPE pipe } \\
(\mathrm{m})\end{array}$ & Cost per $\mathrm{m}$ length & $\begin{array}{l}\text { Total cost for each } \\
\text { diameter of HDPE }\end{array}$ & $\begin{array}{l}\text { Length (Ductile } \\
\text { Iron) (m) }\end{array}$ & $\begin{array}{l}\text { Cost per m length for } \\
\text { D.I. pipe }\end{array}$ \\
\hline 75 & 8 & 262 & 2096 & 0 & 0 \\
\hline 90 & 18,959 & 372 & 7052748 & 0 & 0 \\
\hline 100 & 1,143 & 438 & 500634 & 0 & 0 \\
\hline 110 & 20,056 & 549 & 11010744 & 0 & 0 \\
\hline 125 & 612 & 711 & 435132 & 0 & 0 \\
\hline 150 & 16,294 & 956 & 15577064 & 0 & 0 \\
\hline 200 & 5,824 & 2,297 & 13377728 & 0 & 0 \\
\hline 250 & 2,806 & 3,581 & 10048286 & 0 & 0 \\
\hline 300 & 385 & 4491 & 1729035 & 0 & 0 \\
\hline 315 & 5,188 & 5,677 & 29452276 & 0 & 0 \\
\hline 350 & 0 & 0 & 0 & 0 & 0 \\
\hline 400 & 0 & 0 & 0 & 111 & 3774 \\
\hline 450 & 0 & 0 & 0 & 0 & 0 \\
\hline TOTAL & 71,291 & - & $89,185,743$ & 111 & 418914 \\
\hline \multicolumn{6}{|c|}{ TOTAL cost of pipe (Rs.) } \\
\hline
\end{tabular}

Table 3. Estimation and Costing for Excavation and Filling Work

\begin{tabular}{ccccccc}
\hline Diameter $(\mathbf{m m})$ & $\begin{array}{c}\text { Width Of } \\
\text { trench(m) }\end{array}$ & $\begin{array}{c}\text { Total Length of Pipe } \\
\text { line }(\mathbf{m})\end{array}$ & $\begin{array}{c}\text { Depth of Trench } \\
\text { including Bedding }(\mathbf{m})\end{array}$ & $\begin{array}{c}\text { Quantity } \\
\left(\mathbf{m}^{\mathbf{3}}\right)\end{array}$ & $\begin{array}{c}\text { Cost per } \\
\mathbf{m}^{\mathbf{3}}\end{array}$ & $\begin{array}{c}\text { Total Cost } \\
(\mathbf{R s} .)\end{array}$ \\
\hline 75 & 0.525 & 8 & 1.1 & 4.62 & 165 & 762.3 \\
\hline 90 & 0.54 & 18,959 & 1.1 & 11261.6 & 165 & 1858172 \\
\hline 100 & 0.55 & 1,143 & 1.1 & 691.515 & 165 & 114100 \\
\hline 110 & 0.56 & 20,056 & 1.1 & 12354.5 & 165 & 2038492 \\
\hline 125 & 0.575 & 612 & 1.1 & 387.09 & 165 & 63869.9 \\
\hline 150 & 0.6 & 16,294 & 1.1 & 10754 & 165 & 1774417 \\
\hline 200 & 0.65 & 5,824 & 1.1 & 4164.16 & 165 & 687086 \\
\hline 250 & 0.7 & 2,806 & 1.1 & 2160.62 & 165 & 356502 \\
\hline 300 & 0.75 & 385 & 1.1 & 317.625 & 165 & 52408.1 \\
\hline 315 & 0.765 & 5,188 & 1.1 & 4365.7 & 165 & 720341 \\
\hline 350 & 0.8 & 0 & 1.1 & 0 & 165 & 0 \\
\hline 400 & 0.85 & 111 & 1.1 & 103.785 & 165 & 17124.5 \\
\hline 450 & 0.9 & 0 & 1.1 & 0 & 165 & 0 \\
\hline
\end{tabular}

Table 4. Miscellaneous Expenses

\begin{tabular}{cccc}
\hline Element & No. of pieces & Cost per piece & Total Cost(Rs) \\
\hline T joints & 212 & 220 & 46640 \\
\hline Elbows & 48 & 80 & 3840 \\
\hline End Caps & 177 & 55 & 9735 \\
\hline
\end{tabular}

Table 5. Summary of Total Cost of Project

\begin{tabular}{ccccc}
\hline Description & Cost of pipes & Cost of excavation and filling & Miscellaneous & Total Cost of project \\
\hline $\operatorname{Cost}(\mathrm{Rs})$ & $89,604,657$ & $76,83,275$ & 60,215 & $9,73,84,057$ \\
\hline
\end{tabular}

\section{CONCLUSIONS}

The intermittent water supply system practiced by almost all towns and cities involves serious shortcomings contributing to bad water quality and pressures, deficient quantities, discomfort and inconvenience, contamination etc. Continuous water supply system will handle this suitably. The existing water supply method followed by municipal bodies for cities undergoing shortened supply hours not only does not justify designed hydraulic requirements, but the system is also severely hampered by adverse hydraulics, which lead to many of the key issues affecting local authorities in an avoidable vicious circle. All junctions from both ESRs located at Manisha Nagar and Padmavati in Pandharpur are having pressure greater than or equal to $12 \mathrm{~m}$.

\section{REFERENCES}

Central Public Health and Environmental Engineering Organization (CPHEEO) (1999). Manual on water supply and treatment, Government of India.

Cubillo, F., \& Pérez, P. (2014). Water distribution system risk assessment method. Procedia Engineering, 89, 355-362. https://doi.org/10.1016/j.proeng.2014.11.199

Dahasahasra, S. V. (2007). A model for transforming an intermittent into a $24 \times 7$ water supply system. Geospatial today, 2007(8), 34-39.

Laxman, K. R. (2016). A Geographical Analysis of Horticulture in Solapur District (Doctor of Philosophy), Solapur University, Solapur. 
Pathan, S. S., \& Kahalekar, U. J. (2015). Optimal Design of Water Distribution Network by Using WaterGEMS. International Journal of Pure and Applied Research in Engineering and Technology, 3(8), 308-19.

Punmia, B. C., Jain, A., \& Jain, A. (1995). Water Supply Engineering, Laxmi Publications (P) Ltd., New Delhi.
Rajeshwari, R., \& Kumar, D. B. M. (2014). Evaluation of Intermittent Water Supply System and Design of $24 \times 7$ for a residential area in Mysore, Karnataka, India. International Journal of Informative and Futuristic Research, 1(11), 163173.

Urban Water II (2014). Retrieved from www.witpress.com 